\title{
Irrigation-Induced Changes in Chemical Composition and Quality of Seeds of Yellow Lupine (Lupinus luteus L.)
}

\author{
Justyna T. Polit ${ }^{1, *(1)}$, Iwona Ciereszko ${ }^{2}\left(\mathbb{D}\right.$, Alina T. Dubis ${ }^{3}$, Joanna Leśniewska ${ }^{2}$, Anna Basa ${ }^{4}(\mathbb{D}$, \\ Konrad Winnicki ${ }^{1}$, Aneta Żabka ${ }^{1}$, Marharyta Audzei ${ }^{1}$, Łukasz Sobiech ${ }^{5}{ }^{\circ}$, \\ Agnieszka Faligowska ${ }^{5}$, Grzegorz Skrzypczak ${ }^{5}$ and Janusz Maszewski ${ }^{1}$ \\ 1 Department of Cytophysiology, Institute of Experimental Biology, Faculty of Biology and Environmental \\ Protection, University of Lodz, Pomorska 141/143, 90-236 Lodz, Poland; \\ konrad.winnicki@biol.uni.lodz.pl (K.W.); aneta.zabka@biol.uni.lodz.pl (A.Ż.); \\ avdejka.margo@gmail.com (M.A.); janusz.maszewski@biol.uni.lodz.pl (J.M.) \\ 2 Department of Plant Biology and Ecology, Faculty of Biology, University of Bialystok, Ciołkowskiego1J, \\ 15-245 Bialystok, Poland; icier@uwb.edu.pl (I.C.); joanles@uwb.edu.pl (J.L.) \\ 3 Department of Organic Chemistry, Faculty of Chemistry, University of Bialystok, Ciołkowskiego 1K, \\ 15-245 Bialystok, Poland; alina@uwb.edu.pl \\ 4 Department of Physical Chemistry, Faculty of Chemistry, University of Bialystok, Ciołkowskiego 1K, \\ 15-245 Białystok, Poland; abasa@uwb.edu.pl \\ 5 Agronomy Department, Poznań University of Life Sciences, Dojazd 11, 60-632 Poznań, Poland; \\ lukasz.sobiech@up.poznan.pl (Ł.S.); agnieszka.faligowska@up.poznan.pl (A.F.); \\ grzegorz.skrzypczak@up.poznan.pl (G.S.) \\ * Correspondence: justyna.polit@biol.uni.lodz.pl; Tel.: +48-42-635-45-14
}

Received: 30 September 2019; Accepted: 4 November 2019; Published: 6 November 2019

\begin{abstract}
The quality and amount of yellow lupine yield depend on water availability. Water scarcity negatively affects germination, flowering, and pod formation, and thus introduction of an artificial irrigation system is needed. The aim of this study was to evaluate the influence of irrigation on the quality of yellow lupine seeds. Raining was applied with a semi-solid device with sprinklers during periods of greatest water demand. It was shown that watered plants produced seeds of lesser quality, having smaller size and weight. To find out why seeds of irrigated plants were of poor quality, interdisciplinary research at the cellular level was carried out. DNA cytophotometry evidenced the presence of nuclei with lower polyploidy in the apical zone of mature seeds. This may lead to formation of smaller cells and reduce depositing of storage materials. The electrophoretic and Fourier transform infrared spectroscopic analyses revealed differences in protein and cuticular wax profiles, while scanning electron microscopy and energy dispersive spectroscopy revealed, among various chemical elements, decreased calcium content in one of seed zones (near plumule). Seeds from irrigated plants showed slightly higher germination dynamics but growth rate of seedlings was slightly lower. The studies showed that irrigation of lupine affected seed features and their chemical composition, an ability to germination and seedlings growth.
\end{abstract}

Keywords: endoreplication; FTIR; germination; mitotic activity; SEM-EDS; storage proteins

\section{Introduction}

Yellow lupine (Lupinus luteus L.) is a legume crop which has tremendous economic potential and is of great importance both in sustainable agriculture, particularly in reclamation of marginal lands, and as a natural source of nitrogen thus it could be one of the main species cultivated for green fertilizer, seeds, food and feed. As a rotation crop, it reconstructs the soil after cereals, thus it plays a phytosanitary role. 
Perfectly developed pile root systems of lupine meliorate the soil, making its aeration and watering easier. In this way, it improves the water-air ratio and makes the damaged soil structure (resulting e.g., from cereal monoculture) more crumbly. As a result of symbiosis with papillary bacteria, lupine has the ability to bind indirectly free atmospheric nitrogen and, thus, to improve soil fertility. Its long roots take up ions of calcium, magnesium, potassium and phosphorus from deep layers of soil, inaccessible for other plant species. Thus, it increase the yield of follow-up crop, because the compounds stored in the tissues (macro- and micronutrients) return to the soil from crop residues (such as roots or straw), remaining after the harvest or when lupine plants are intended for plowing as a green fertilizer [1-5]. Yellow lupine contains a large amount of high quality proteins in its seeds and negligible amounts of harmful, bitter alkaloids. These proteins, due to the favorable amino acid composition, are of much higher quality than those derived from cereal grains. Therefore, the seeds are used as a protein source in the diets of livestock, and also as a component of food, especially functional food for people [1,4-9]. The lupine proteins have pharmaceutical qualities. They influence lipid and glucose metabolism as well as blood pressure. They may also affect inflammatory processes and changes in gut microbiome. This has a significant influence on the metabolism, nutrient absorption, and immune functions [4,10-12]. In addition, yellow lupine seeds are abundant in the Fe-rich ferritin and may be a safe way to increase dietary iron intake replacing traditional iron supplementation methods [13].

Yellow lupine is a species with the lowest soil requirements among other lupine plants, however, is characterized by a relatively long growing season until the seeds are produced. The atmospheric conditions prevailing at this time may both favor or impair the course of cultivation. During vegetation its yielding is unstable under unfavorable weather conditions, such as drought [5,9]. Due to this, it is not willingly grown despite its beneficial properties. Therefore, it is difficult to achieve such amounts of this high-protein crop seeds that could be competitive with soya, which now satisfies great part of nutritional needs, especially in Europe [4].

Thanks to the well-developed root system, plants of yellow lupine can cope with periodic water shortages, taking it from deeper soil layers, inaccessible for other herbaceous plants. However, long-lasting drought causes changes at the physiological and molecular level. Lack of water or its insufficient amount prolongs the flowering period. Water shortage activates stress responses and decreases the numbers of both flowers and developing pods, thus limiting lupine yield $[5,9,14-16]$. Drought inhibits the development of symbiotic bacteria from the Rhizobium group, and consequently decreases the total plant mass. In addition, water-deficit conditions can influence seed chemical composition, e.g., increasing alkaloid content in some sweet lupine varieties making them less attractive for farm animals [2,14-18]. Generally, shortage of water increases the production of reactive oxygen species in cells (which may cause damages in photosystems, especially PSII and in membranes of thylakoids), and decreases the rate of photosynthesis, due to low $\mathrm{CO}_{2}$ uptake, a lowered activity of photosynthetic enzymes and reduced chlorophyll content [17,19-24]. All changes in plant metabolism which ensure survival of unfavorable conditions limit crop yield [18,21,25]. Every reduction of agricultural productivity causes economic losses among farmers and increases food prices [26,27].

Complexity of plant response to water deficit makes genetic research that could lead to obtaining drought-resistant crops difficult and time-consuming [4,20,21,24]. Thus, different methods of irrigation are still the most common approach to reduce adverse effects of drought in agriculture. It was found that they increase crop productivity and seeds quality, [18,25,28-33]. However, contradictory results concerning the lupine are also known, and they indicate that irrigation might reduce seed vigor, germination capacity and germination energy, but increase a share of mold, rotting, and dead seeds [34,35]. It is therefore necessary to analyze whether irrigation is beneficial in all circumstances, even when plants are exposed only to mild water stress. If the seeds are to be used for consumption purposes, a specially high level of quality is desired, but if they are treated as a planting material, it is possible that mild drought will increase plant resistance to stress and the memory of stress will help to tolerate unfavorable conditions by the next generation of plants.

The aim of the current research was to investigate cytological, chemical and biochemical traits which may be responsible for quality of seeds from irrigated plants of yellow lupine. The obtained results 
indicate that the seeds harvested from the non-irrigated and irrigated plants differ in size and weight, endopolyploidy level of cotyledon cells, content of storage proteins, protein composition and in cuticular wax profiles, as well as they differ in the germination capacity and growth rate of embryonic roots.

\section{Results}

\subsection{Seed Yield}

Irrigation did not improve the seed yield of the yellow lupine. The amount of yield collected from the main stem as well as from branches of irrigated plants was comparable to that obtained from the control (non-irrigated) plants (Table 1). However, the seed yield was visually of inferior quality. For clarity, in the following sections of the work the seeds collected from the plants growing under natural conditions (without additional irrigation) are referred to as "control seeds" whereas the seeds from the plants subjected to irrigation are referred to as "irrigated seeds".

Table 1. Seed yield of yellow lupine [g/plant] harvested from the main stems, branches and whole control (not irrigated) and irrigated plants.

\begin{tabular}{cccc}
\hline & Main Stem & Branches & Plant \\
\hline Control & 3.68 & 0.38 & 4.06 \\
Irrigation & 4.14 & 0.94 & 5.08
\end{tabular}

All differences between presented pairs of mean values of seed weights are not statistically significant (the Student's $t$-test, $p<0.01)$.

\subsection{Seed Morphology}

In both control and irrigated plants there were seeds of different morphology and quality. Therefore the control and the irrigated seeds were divided into normal (correct) and abnormal (incorrect) groups due to differences in their morphological state (Figure 1a-d).
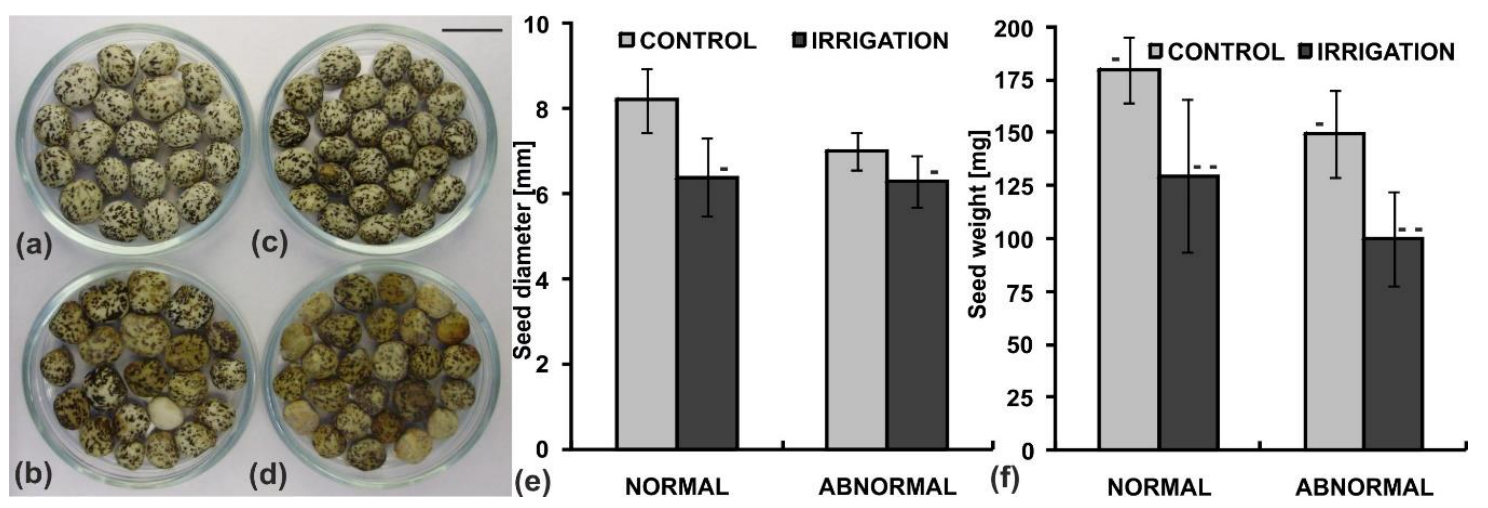

Figure 1. Seeds of yellow lupine collected from the control (not irrigated) and irrigated plants and sorted according to morphological features: (a) control—normal seeds, (b) control—abnormal seeds, (c) irrigated plants—normal seeds, (d) irrigated plants—abnormal seeds. Scale bar $10 \mathrm{~mm}$, (e) seed size (diameter) measured along the long axis, (f) seed weight. Statistical significance between mean values of seed diameters and seed weights was assessed with the Mann-Whitney U test $(p<0.01)$ and Student's t test $(p<0.01)$, respectively. Error bars represent standard deviation (SD). Minuses and double minuses indicate pairs of statistically insignificant results.

The evaluation was based on seeds color, shape, estimated size and weight. Seeds from the first group were relatively large in size and weight, smooth, oval-shaped and slightly flattened, covered with a white seed coat with a specific regular marble pattern. The seeds from the second group were significantly smaller or lighter, with distorted oval shape, often stained brownish or without the clear marble pattern. The above-mentioned poor morphological features, occurred separately or accumulated in one seed. 
The lupine seeds in each group were measured and weighed. It turned out that the yield of the irrigated plants was of inferior quality (Figure 1e,f). Their seed size and weight were smaller by about $25 \%$ and about $30 \%$, respectively. Because the percentage of abnormal seeds in both groups of plants was similar, i.e., $32 \%$ and $30 \%$ for the control and irrigated plants, respectively, as well as about $35-40 \%$ of the abnormal ones did not germinate, in subsequent studies only normal seeds were taken into account.

\subsection{DNA Content}

Mature seeds of lupine have large cotyledons; their cells, depending on the area in which they are located, may be of different ploidy level and thus may occur at different sizes. Cytophotometric measurements of DNA content in the cell nuclei of two extremely situated cotyledon zones (basal and apical; Figure 2) in the control seeds did not reveal differences (Figure 2b,c). In both zones, besides the $2 \mathrm{C}$ and $4 \mathrm{C}$ DNA cells (nearly $70 \%$ ), polyploid ones were also observed (about $30 \%$ ). More than $20 \%$ of them passed the first round of endoreplication and contained $8 \mathrm{C}$ DNA, while about $7 \%$ passed two rounds of endoreplication reaching 16C DNA. A few (about 2\%) contained 32C DNA.
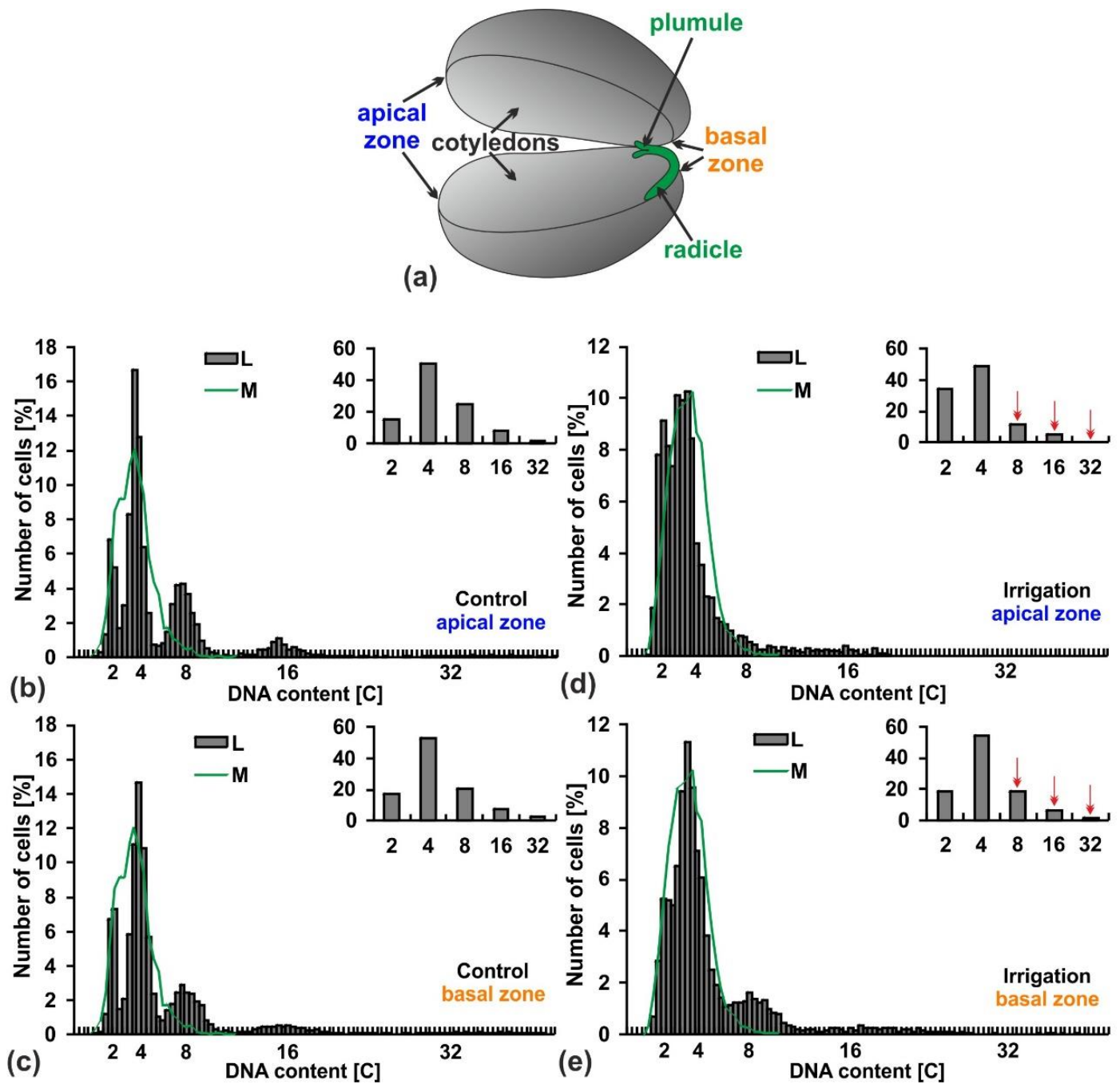

Figure 2. DNA content in the indicated zones of yellow lupine seeds. (a) Structure of lupine seed. (b-e) Frequency distribution [\%] of nuclear DNA content in the selected zones: cotyledon zones (L) and root meristems (M) of yellow lupine; (b) Apical zone of control seeds from not irrigated plants. (c) Basal zone of control seeds from non-irrigated lupine plants. (d) Apical zone of seeds from irrigated plants. (e) Basal zone of seeds from irrigated plants. Inserted bar graphs show percentages of cells after successive rounds of endoreplication. Red arrows show a decrease in the number of polyploid cells in the seeds from irrigated plants. 
In the irrigated seeds there was a weakly pronounced difference in the number of polyploid cells in the basal zone of cotyledons (less by only $3 \%$ ), while a significantly lower number of them (less by $17 \%$ ) was observed in apical zone (Figure $2 \mathrm{~d}$,e). In this zone, cells with $2-4 \mathrm{C}$ DNA content characteristic of the regular cell cycle accounted for $84 \%$ and polyploid ones for only $16 \%$ (Figure $2 \mathrm{~d}$ ). A decrease in the number of polyploid nuclei was mainly related to a significant quantitative reduction of the cells in the first round of endoreplication (Figure 2e).

\subsection{Protein Profiles}

Electrophoretic distribution of the proteins in the polyacrylamide gel allowed us to assess protein composition of the control and irrigated seeds (Figure $3 a, b)$. The same number of distinguishable bands in both channels indicated the presence of similar protein composition in the tested seeds. The digital analysis of the intensity of their staining pointed to some differences in the amount of proteins present in them (Figure $3 b$ ). Even a small difference in the height of the bars (staining intensity) in each pair, e.g., band pairs 6 or 14 (Figure $3 b$ ) is clearly visible in the polyacrylamide gel (containing proteins of about 62 or $17 \mathrm{kDa}$, respectively; Figure 3a).
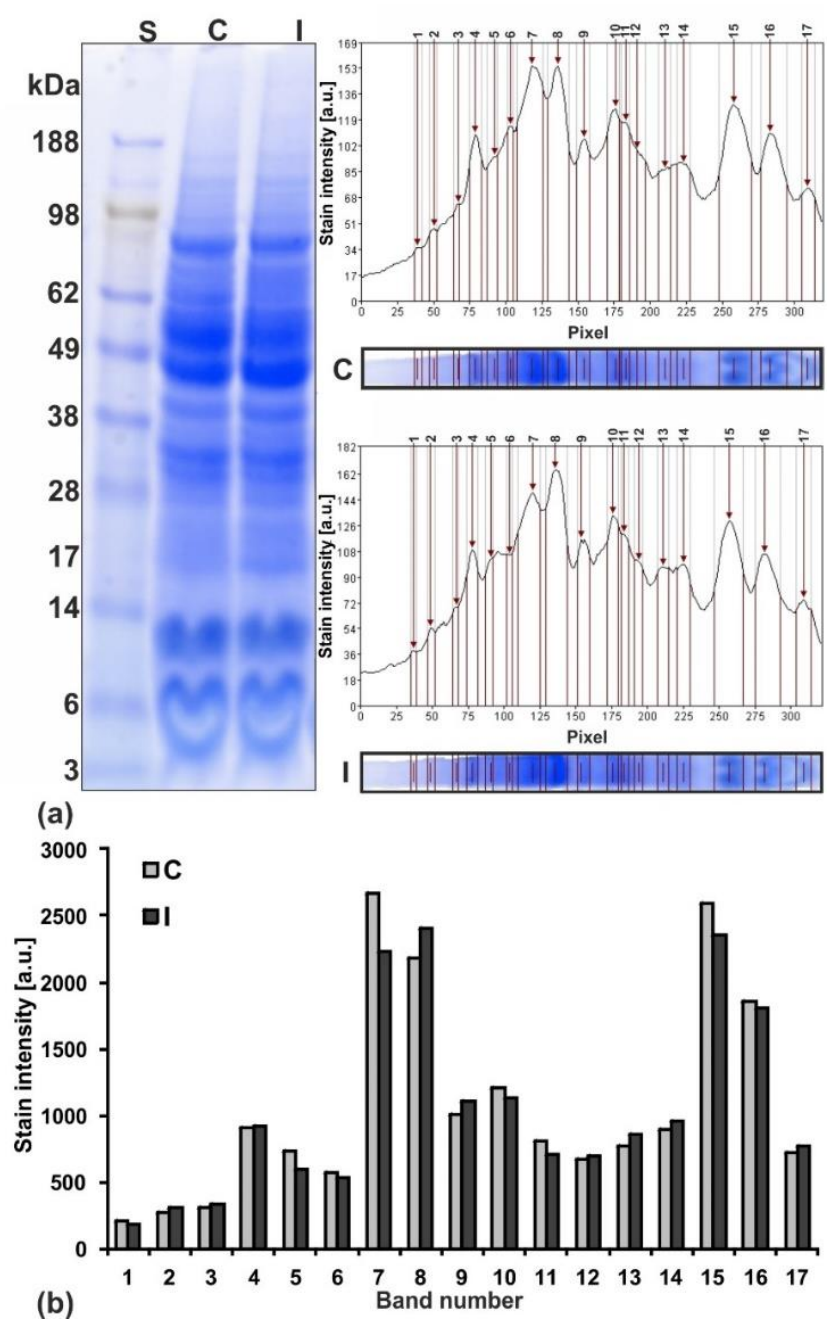

Figure 3. Protein profile in yellow lupine cotyledons from the seeds collected from not irrigated-(control C) and irrigated-(I) plants. (a) Electrophoretic separation of proteins in polyacrylamide gel (stained with Coomassie Blue) and computer analysis of staining intensity of the detected bands. Channel 1 shows protein mass standard (S), two and three show seed proteins from non-irrigated (control C) or irrigated (I) plants, respectively. (b) Comparison of protein contents in 17 detected bands. 
The most stained bands $(4,7,8,15,16,17$; Figure $3 \mathrm{~b})$ contained subunits of storage proteins (the most abundant in cotyledones of lupine): albumins, i.e., $\delta$-conglutin, globulins, e.g., $\beta$-conglutin (vicilin-like), and $\alpha$-conglutin (legumin-like), as well as probably a non-storage protein, $\gamma$-conglutin. In comparison with control plants, the decrease in storage protein content in some bands (seven cases), and the increase in others (eight cases) indicated modifications of their proportions due to irrigation.

\subsection{Fourier Transform-Infrared Spectroscopy (FT-IR) Analysis of Lupine Seeds}

The diffuse reflectance infrared spectroscopy (DRIFTS) FT-IR spectra of dry peeled lupine seeds from control and irrigated plants are shown in Figure $4 a-c$. The spectrum of the every dry lupine seed exhibit two prominent absorption bands at 3314 and $1674 \mathrm{~cm}^{-1}$ which could be assigned to N-H and $\mathrm{C}=\mathrm{O}$ stretching bands (Figure 4a). There are also three prominent bands which appear in the 2955-2855 $\mathrm{cm}^{-1}$ range that originate from the hydrocarbon tails. For methyl $\left(\mathrm{CH}_{3}\right)$ and methylene $\left(\mathrm{CH}_{2}\right)$ groups, asymmetric and symmetric C-H stretching occur at 2955, 2925 and $2855 \mathrm{~cm}^{-1}$, respectively. Triglyceride ester group show carbonyl $\mathrm{C}=\mathrm{O}$ band at $1745 \mathrm{~cm}^{-1}$. The major infrared modes due to protein give rises to amide carbonyl modes in the $1700-1620 \mathrm{~cm}^{-1}$ range. This region consists of some overlapping carbonyl bands which may be separated using the Fourier self-deconvolution mathematical method (FSD) [36]. One of the examples of improvement of information content by using FSD method is the estimation of protein secondary structure and conformations by the analysis of the resolution-enhanced amide I profile by FSD [37].
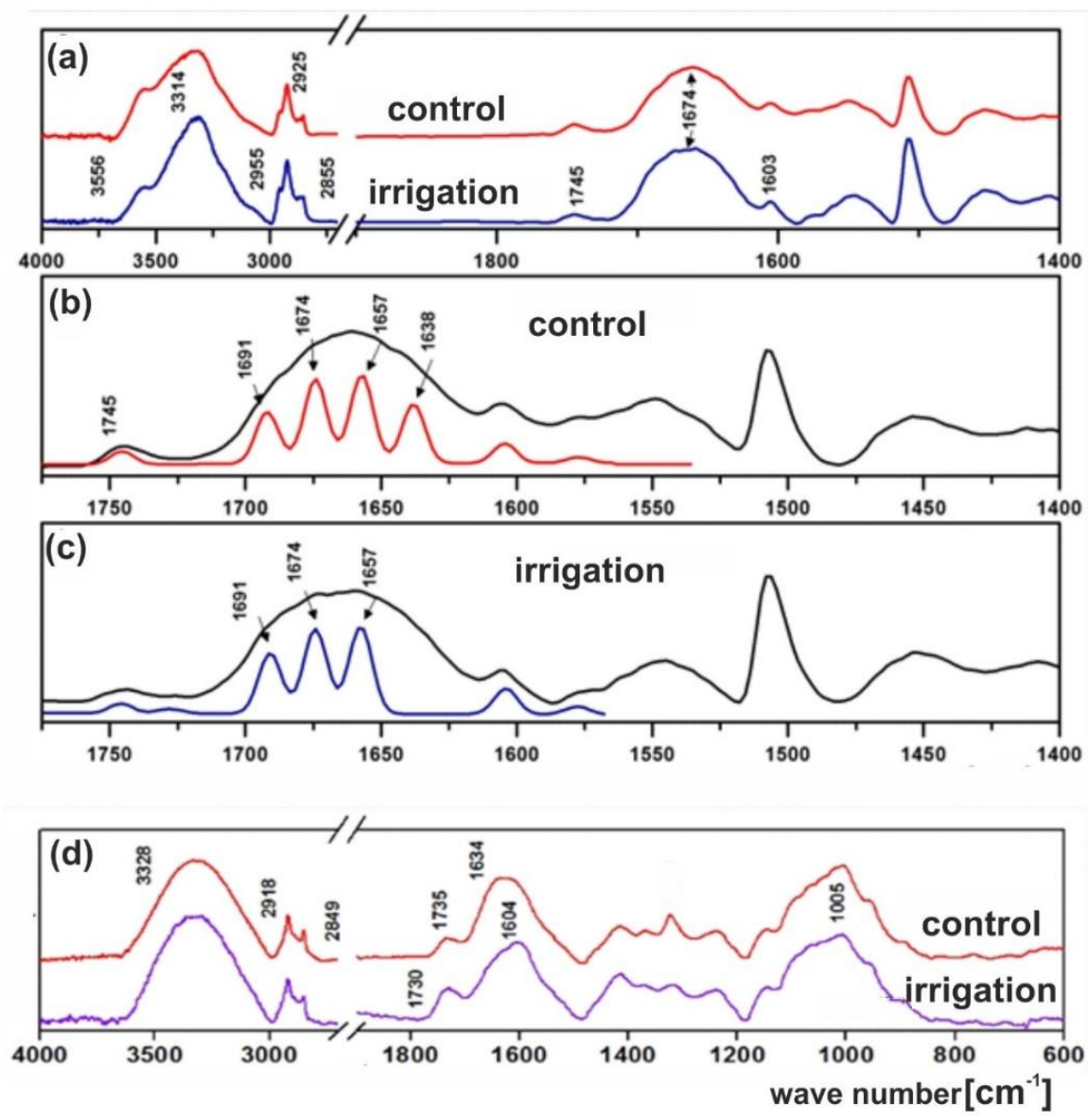

Figure 4. Fourier transform-infrared spectroscopy (FT-IR) spectrum of the yellow lupine seeds: (a) peeled seeds collected from the control (not irrigated) and irrigated lupine plants, (b) separation of the overlapping bands in the spectrum of the control seed-four Gaussian lines (red line) were found at $1691,1674,1657$ and $1638 \mathrm{~cm}^{-1}$, (c) separation of the overlapping bands in the spectrum of the irrigated seed-three Gaussian lines (navy line) were found at 1691, 1674, and $1657 \mathrm{~cm}^{-1}$. Spectra were recorded 
at room temperature using the diffuse reflectance infrared spectroscopy (DRIFTS) module. (d) attenuated total reflection (ATR)/FT-IR spectrum of the lupine seed coat cutine from the control and irrigated material. Spectra were recorded at room temperature using ATR module.

The spectra of proteins exhibit absorption bands associated with amide groups. The exact wave numbers of $\mathrm{C}=\mathrm{O}$ vibrations depend on the nature of hydrogen bonding interaction involving $\mathrm{C}=\mathrm{O}$ and $\mathrm{N}-\mathrm{H}$ groups. The characteristic bands of the amide groups of protein chains are similar to the absorption bands exhibited by secondary amides, and are labelled as amide I bands. It occurs between 1700 and $1600 \mathrm{~cm}^{-1}$.As a consequence of inter- and intramolecular interactions, the amide I bands consist of a number of overlapping component bands. The FSD-IR was used to extract individual components from a complex composite band of $\mathrm{C}=\mathrm{O}$ groups. Using the deconvolution method, the $v_{\mathrm{C}=\mathrm{O}}$ characteristic stretching bands at $1691,1674,1657,1638 \mathrm{~cm}^{-1}$ were estimated in the control material (Figure $4 \mathrm{~b}$ ). It seems most likely that changes in the composition of the seed storage proteins are due to the irrigating process (Figure $4 \mathrm{a}$, navy line). There was no absorption band at $1638 \mathrm{~cm}^{-1}$ (Figure 4C, navy line), as compared with the spectrum of the control lupine seeds (Figure 4b, red line). We believe that the difference of wave number reflects the structural nonequivalence of carbonyl groups. It means that various protein types are present in the lupine seeds.

Figure $4 \mathrm{~d}$ shows attenuated total reflection (ATR)/FT-IR spectra of lupine seed coats. There are four main absorption bands. The broad and intense band at $3328 \mathrm{~cm}^{-1}$ was assigned to the $\mathrm{O}-\mathrm{H}$ stretching modes of alcohols and fatty acids. The bands in the region of $2918-2849 \mathrm{~cm}^{-1}$ were assigned to the stretching of aliphatic $\mathrm{CH}_{2}$ groups. The band at $1735 \mathrm{~cm}^{-1}$ was assigned to the $\mathrm{C}=\mathrm{O}$ mode of carbonyl ester group. The broad band centered at $1634 \mathrm{~cm}^{-1}$ are due to proteins. The intense band at $1005 \mathrm{~cm}^{-1}$ is assigned to $\mathrm{C}-\mathrm{O}$ vibration of cellulose [38].

The spectroscopic analysis demonstrated that the cuticular wax profiles of the irrigated seeds was different from the control ones. The absorption band assigned to the $\mathrm{C}=\mathrm{O}$ mode of ester group was more intensive for the former ones. The broad band characteristic of proteins centered at $1634 \mathrm{~cm}^{-1}$ from non-irrigated seeds and at $1604 \mathrm{~cm}^{-1}$ from irrigated ones, as well as the broad band (characteristic of cellulose) centered at $1005 \mathrm{~cm}^{-1}$ also showed some differences.

\subsection{Analysis of Chemical Elements by the SEM/Energy Dispersive Spectroscopy (EDS) Technique}

In the seeds of yellow lupine three chemical elements, $\mathrm{C}, \mathrm{O}$ and $\mathrm{N}$, were dominant. Their contents in each analyzed zone were similar in the control and irrigated seeds (Figure 5). Other elements $(\mathrm{Mg}$, $\mathrm{Al}, \mathrm{P}, \mathrm{S}, \mathrm{K}, \mathrm{Ca}$ ), whose contents (expressed in weight \%) oscillated on average around $0.5 \%$ showed no statistically significant changes after irrigation treatments (Figure 5c). Among these various studied elements only the calcium content decreased statistically significantly in one seed zone (in the cotyledon near plumule), probably as a result of plant irrigation. 


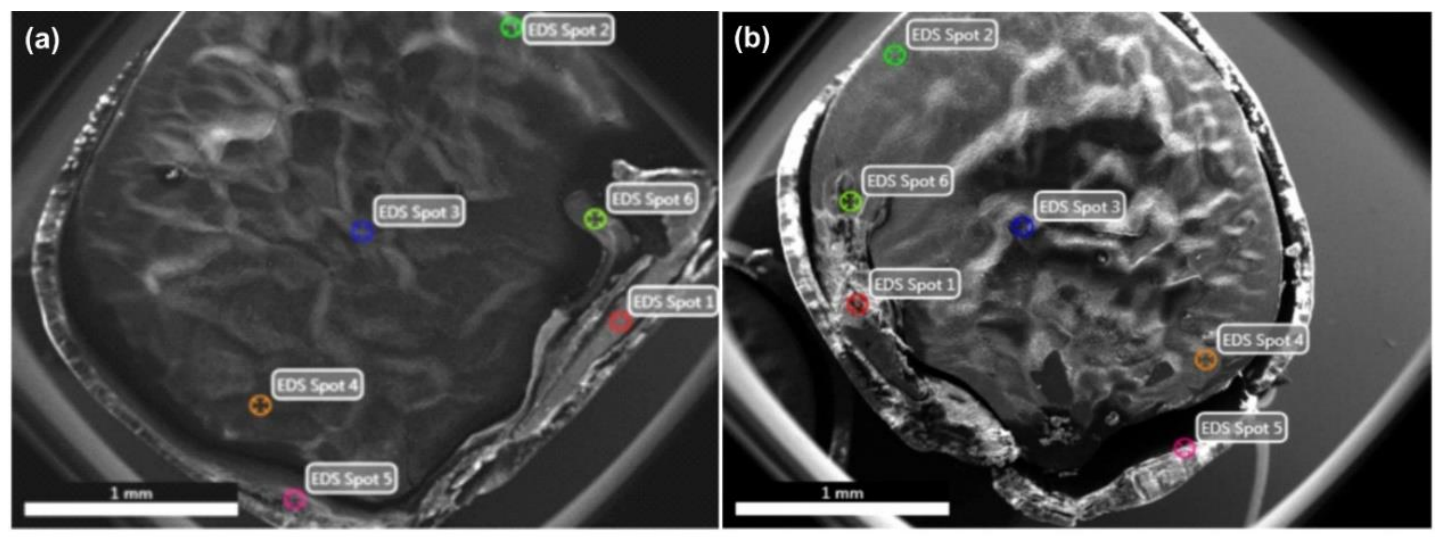

(c)

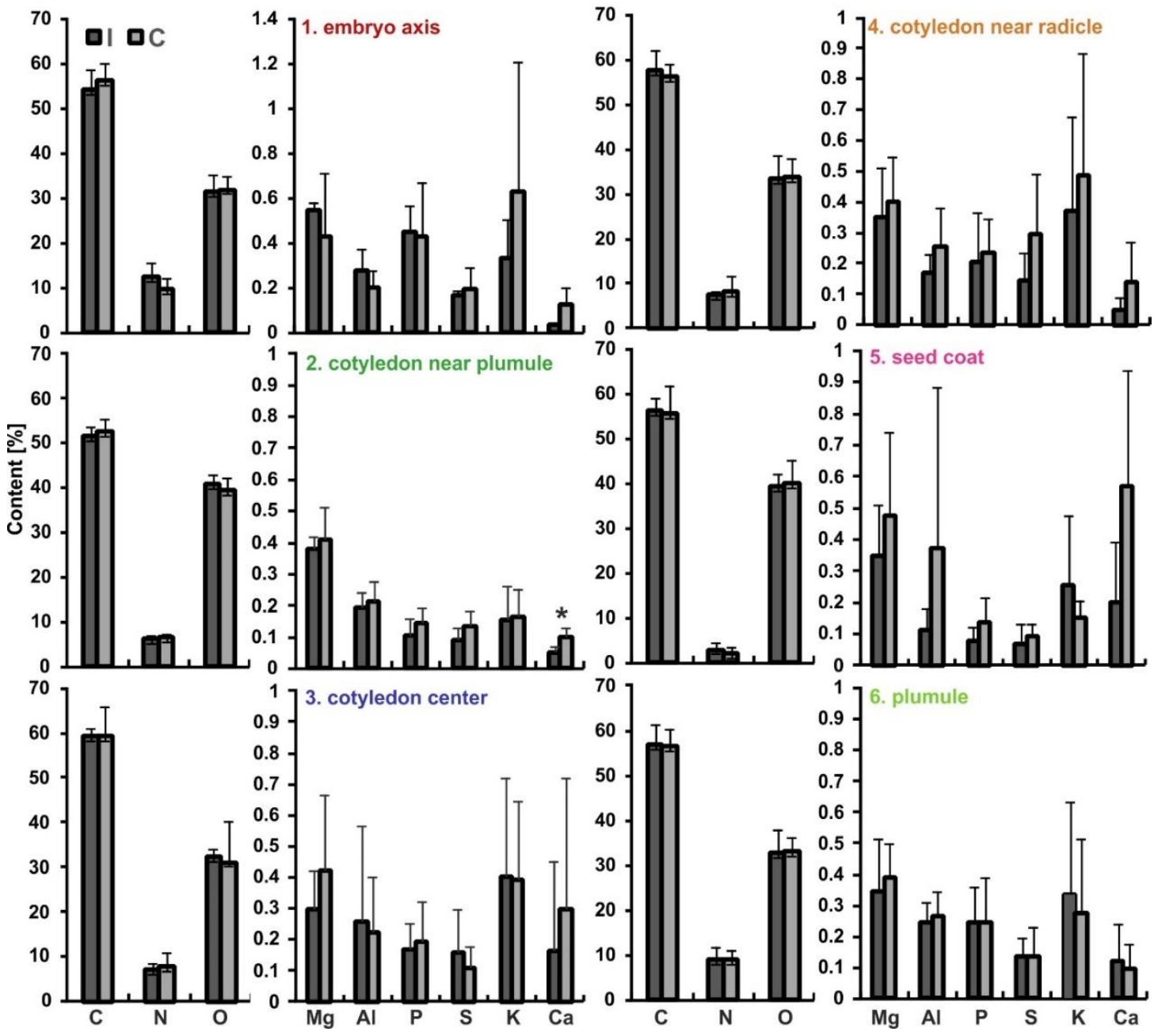

Figure 5. Scanning electron microscope (SEM) micrographs of yellow lupine half seeds: (a) Seed of a control plant. (b) Seed of an irrigated plant. The spots: 1-embryo axis, 2-cotyledon near plumule, 3-cotyledon center, 4-cotyledon near radicle, five-seed coat, six-plumule. (c) Corresponding content (weight \%) of chemical elements ( $, \mathrm{N}, \mathrm{O}, \mathrm{Mg}, \mathrm{Al}, \mathrm{P}, \mathrm{S}, \mathrm{K}, \mathrm{Ca}$ ) in the indicated zones of seeds (C-control, I-irrigated plants, respectively). Statistical significance between mean values was assessed with the Student's t-test $(p=0.008)$. Error bars represent standard deviation (SD). An asterisk indicates statistically significant results. 


\subsection{Germination and Seedlings' Growth}

Substances stored in a storage tissues (for example in the cotyledons) are used during germination and growth of young seedlings. The dynamics of germination and growth are the parameters that allow to evaluate seed quality. The seeds collected from control and irrigated plants (only correct, as described in the Section 2.1., Figure 1) were germinated for three days (Figure 6). The seeds that did not sprout after three days did not sprout at all; they constituted $13 \%$ and $20 \%$ in the control and irrigated seed lots, respectively. After the first day of germination as much as $23 \%$ of the irrigated seeds sprouted out, while in the control there was almost half as much, only $13 \%$ (Figure 6a). In both groups of seeds the vast majority sprouted after two days. However, the overall percentage of germinated seeds was higher in the control (72\%) than those in the irrigated material (49\%).
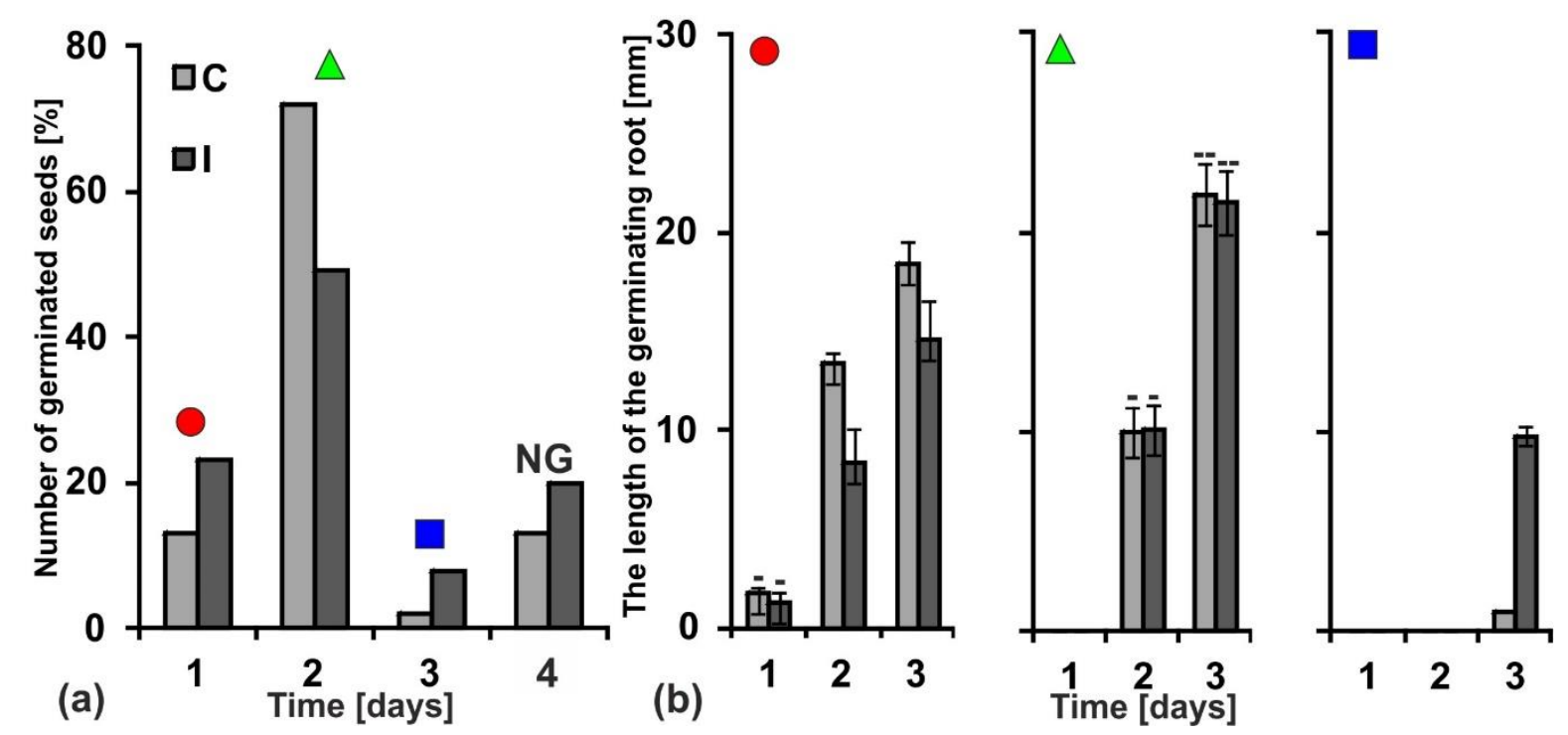

Figure 6. The dynamics of yellow lupine seed germination and growth of embryo roots. (a) Percentage of germinated seeds during three days. The seeds collected from not irrigated plants (control C). The seeds collected from irrigated plants (I). The seeds which remained non-germinated (NG) after four days. Black figures (circle, triangle, square) above bars indicate populations of germinated seeds whose root length is presented on the graphs marked with an adequate figure in part (B). (b) Dynamics of embryo roots growth during following days of germination. Statistical significance between mean values in diagram marked with black circle and triangle was assessed with the Mann-Whitney U test $(p<0.01)$ and the two-way ANOVA with the post-hoc unequal N HSD (honest significant difference) Tukey test $(p<0.01)$, respectively. Error bars represent standard deviation (SD). Minuses and double minuses indicate pairs of statistically insignificant results.

Among the seeds that germinated after the first day, the control seedlings grew faster, whereas among those that germinated later (after two days) both control and irrigated seedlings grew similarly and finally reached larger sizes than the first ones (Figure $6 b$ ).

\subsection{Mitotic Activity}

Cell proliferation in meristems is one of the main causes of seed germination and growth of the embryonic roots. Both after the first and the second day of germination, the differences between the mitotic indexes evaluated for root meristems in seeds of the control and irrigated plants were statistically not significant (Figure 7a). However, after the first day of germination in roots growing from the control seeds, cell divisions started with greater synchronization, as evidenced by the high prophase index (more than $45 \%$; Figure $7 \mathrm{~b}$ ). 

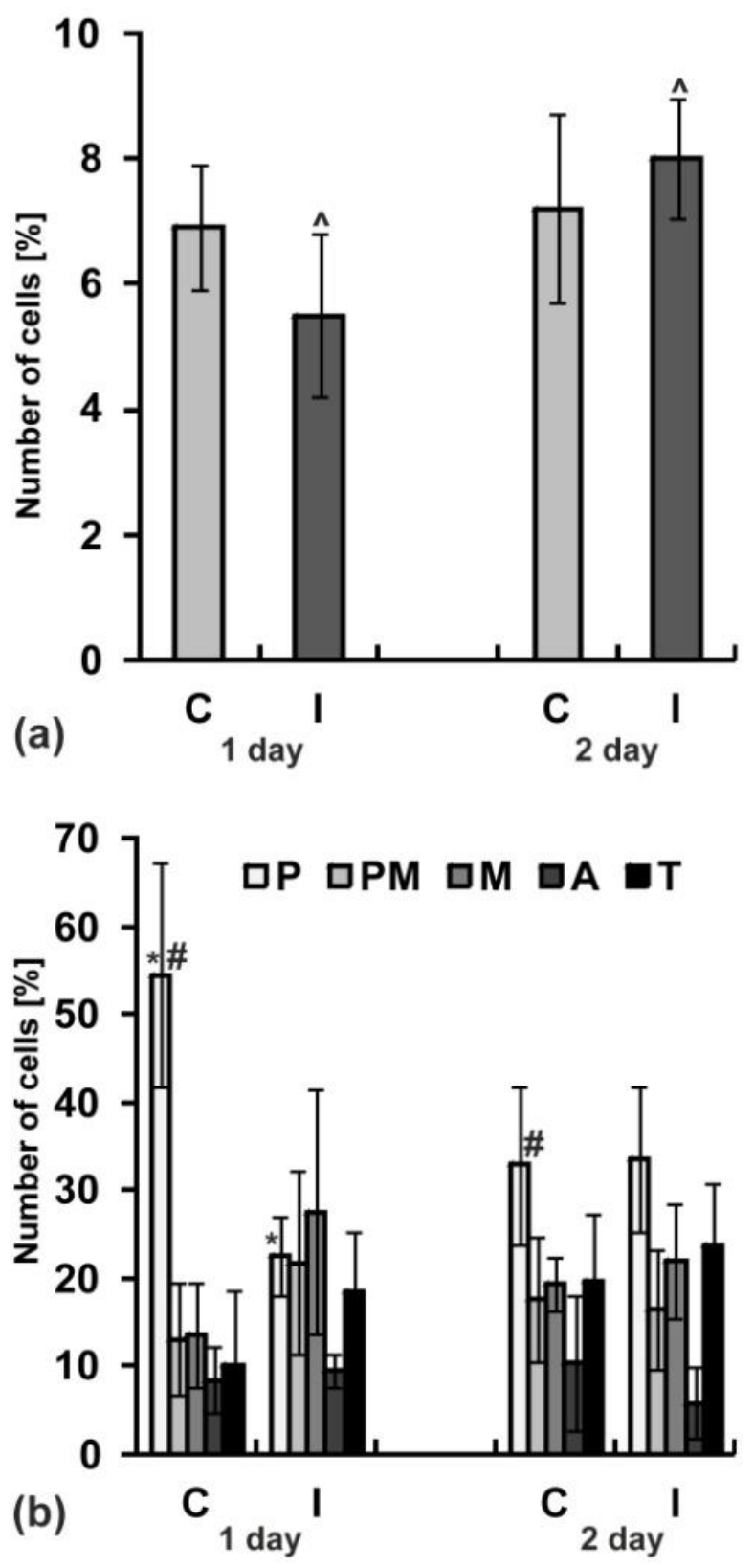

Figure 7. Mitotic activity in yellow lupine root meristems after one and two days of seed germination. The seeds collected from not irrigated (control-C) and irrigated-I plants. (a) Mitotic index, (b) phase index, $\mathrm{P}$-prophase, $\mathrm{PM}$ - prometaphase, $\mathrm{M}$-metaphase, $\mathrm{A}$-anaphase, $\mathrm{T}$-telophase. Statistical significance between mean values was assessed with the two-way ANOVA and post-hoc unequal $\mathrm{N}$ HSD Tukey test $(p<0.01)$. Error bars represent standard deviation (SD). Pairs of symbols $(\wedge, *$,\#) over the bars indicate pairs of statistically significant results.

\subsection{Detection of Hydrogen Peroxide}

During germination of seeds, reactive oxygen species (e.g., hydrogen peroxide $-\mathrm{H}_{2} \mathrm{O}_{2}$ ) are produced in the embryo roots of young seedlings. Their appropriate level is necessary to promote changes in the structure of a cell wall and to facilitate elongation of cells. On the other hand, $\mathrm{H}_{2} \mathrm{O}_{2}$ is also a dangerous compound which adversely affects the cells. Too high a level of $\mathrm{H}_{2} \mathrm{O}_{2}$ causes double-strand DNA breaks and destroys the structure of chromosomes. Analyses of the $\mathrm{H}_{2} \mathrm{O}_{2}$ content (based on the 3,3-diaminobenzidine (DAB) polymerization method) revealed that its level was similar in the roots grown from the control and irrigated seeds (Figure 8). 

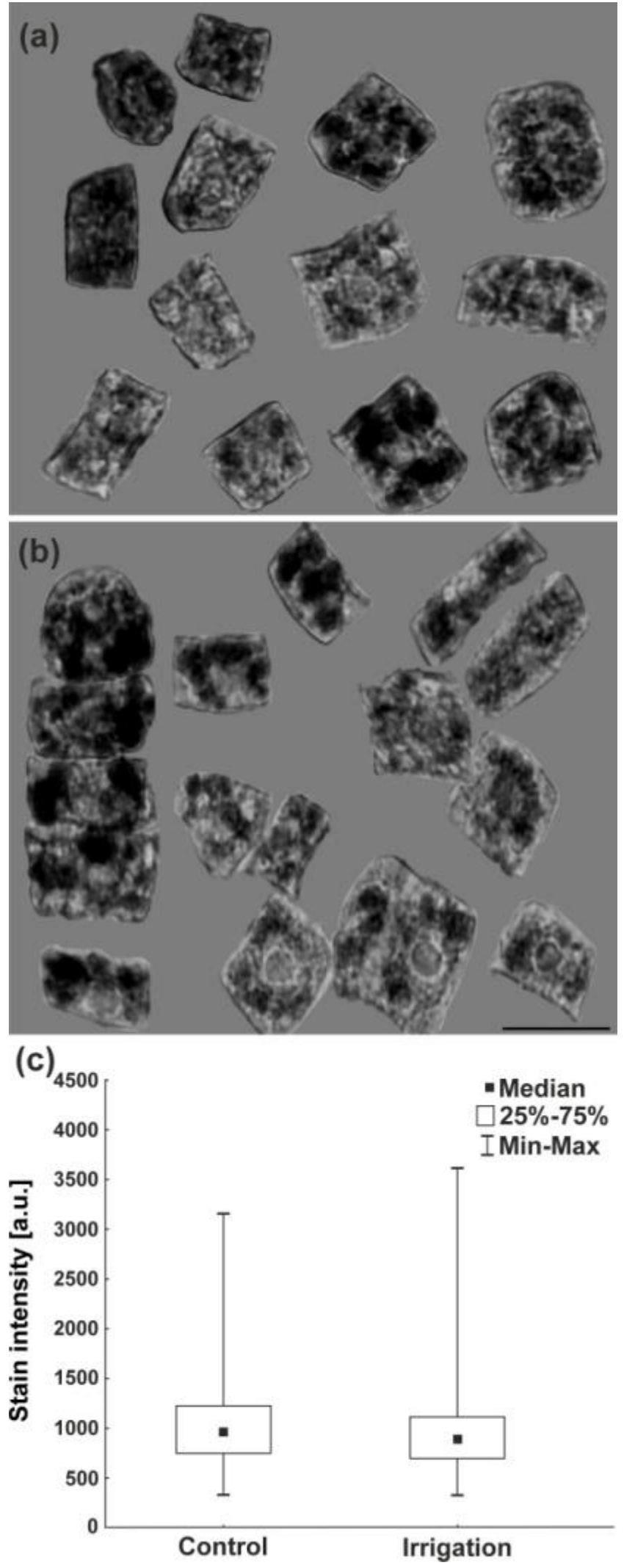

Figure 8. Identification of $\mathrm{H}_{2} \mathrm{O}_{2}$ in the form of dark 3,3-diaminobenzidine (DAB) polymers and the level of $\mathrm{H}_{2} \mathrm{O}_{2}$ in the cells of embryonic roots deriving from lupine seeds. (a) Not irrigated-control plants. (b) Irrigated plants. Scale bar $20 \mu \mathrm{m}$; (c) stain intensity (arbitrary units) in these cells. Statistical significance between median values was assessed with the Mann-Whitney U test $(p<0.01)$. Median values are statistically insignificant. 


\section{Discussion}

Due to the advantages of yellow lupine cultivation, treatments aimed at counteracting adverse natural conditions as well as research studies that monitor plant reactions to the prevailing and modified growing conditions are justified. In the future they will allow to increase the yield or keep it at a predictable level for years characterized by changing weather, and thus will encourage farmers to grow this species. One of the commonly used agrotechnical methods that could prevent water shortages, ensure the correct rhythm of plant development and intensify yields, is crop irrigation [5,39]. It causes an increase in the yield of cereals (up to $27 \%$ ) and also improves the amount and quality of some legume seeds like chickpea beans $[31,39]$. However, this common agronomic operation has not been optimized for lupine seed harvest yet. Generally, lupine plants are sensitive to water deficit and intolerant of waterlogging but stress response depend on the species and plant condition. It was found that plants belonging to one genus-Lupinus react differently to new conditions caused by unfavorable weather occurring over the growing season [5,18,40-42]. Therefore, it is extremely important to optimize the growing conditions for an individual species. Surprisingly, current studies showed that irrigation of yellow lupine (L. luteus L. cultivar Mister) did not significantly increase yields, while it weakened the quality of seeds. Seed size was smaller by about $25 \%$ and the weight-by about $30 \%$. However, the yield of narrow-leaved lupine cultivated at the same time and under the same irrigation conditions was even 2.5 times higher than of the non-irrigated plants, although the quality of irrigated seeds was also worse in terms of size and weight [43]. Thus, yellow lupine seems to grow better under water shortage than under the conditions limiting this stress. In turn narrow-leaved lupine showed greater tolerance of the new created cultivation conditions, as the decreases in size and weight of seeds were smaller than in the case of yellow lupine. This could be the result of the anatomical structure of narrow-leaved lupine leaves, which allowed more efficient drying of the lupine field, and thus created better conditions for seed maturation.

Seed size and weight are important physical indicators of seed quality that affects vegetative growth of the next generation of plants (e.g., seedlings' vigour); both parameters are frequently related to the size of yield, market grade factors and harvest efficiency [44]. Generally, large seeds (e.g., of wheat, rice, oat, safflower, chickpea, sugar beet and many others species of plants) have better field performance than small seeds [44]. However, some researchers showed that cultivars of pea with lower seed mass displayed better germination than those with larger seeds [45]. Furthermore, small seeds of soybean had better germination and storage reserves utilization, as well as seedlings uniformity, which grown much faster than those from larger seeds [46]. Additionally, small seeds of safflower germinated faster and plants thereof grew higher under saline conditions [47].

To find out why yellow lupine seeds were of poor quality (mostly regarding their size and weight), the interdisciplinary research at the cellular level was carried out. To the best of our knowledge research involving microscopic, cytological, biochemical, and chemical analyses of seeds collected from the irrigated and non-irrigated yellow lupine plants has never been conducted so far.

Cytophotometric analyses of nuclei from cotyledon cells of seeds collected from the irrigated yellow lupine plants revealed lower ploidy level than those from the control plants. As demonstrated in numerous studies, polyploidization plays a key role during plant tissue and organ growth and development, both in favorable conditions and during environmental stress. A positive correlation between ploidy level and cell size, was observed in many plants, and was defined as the karyoplasmic ratio theory, which suggests that an increase in nuclear DNA content can be a driving force for cell expansion [48-50]. This mechanism seems to be advantageous especially when energy is limited, when rapid growth is necessary, or when terminal differentiation of some cells and their specialized functions are needed [51]. Cotyledons of lupine seeds are a reservoir of storage materials (mainly proteins) for developing embryos and growing young seedlings and should grow quickly during seed development to create space for the synthesized substances [51-53]. Endoreduplication associated with the production of storage materials is very common, although in some studies the correlation between endoreduplication and accumulation of storage proteins was not observed [54]. Different 
environmental factors can also have strong impact on the genome size [50,55-58]. Our research revealed that plant irrigation may be an inhibitory factor against switching of the classical cell cycle to the endocycles. Hence low level of ploidy in the cotyledon cell nuclei may be responsible for small seed sizes. The mechanism of this process is unknown, however it was suggested that only the ccs52 protein and protein inhibitors of cyclin-dependent kinases are of crucial importance in this case, as they inhibit cell entry into mitosis and promote endocycles $[59,60]$. The ploidy reduction in seeds of irrigated plants is not accidental because it was observed not only in yellow lupine but also in narrow-leaved lupine. Moreover, limitation of endoreplication, mainly in the apical zone of the seeds of both plant species, is of particular interest. This indicates the existence of a characteristic response mechanism which may be associated with the sequence of deposition of the storage compounds in specific seed areas.

Yellow lupine seeds are characterized by high protein content $(44 \%)$, even higher than that in soybean (35\%), white lupine ( $40 \%$ ), and narrow-leaved lupine (34\%), and thus, may be considered as a source of high quality storage proteins because of their nutritional, functional and chemical properties. Therefore preservation of the proper composition of proteins in lupine seeds during agro-technical treatments is of great importance. The lupine storage proteins are mainly globulins, which include $\alpha$-, $\beta$ - and $\gamma$-conglutin and their composition may differ in individual species of lupine [1,61-64]. Changes in DNA content in cotyledon cells caused by plant irrigation also encouraged us to make comparative analysis of protein profiles, because environmental stress factors may change gene expression, protein composition and their chemical structure [65-67]. The electrophoretic and spectroscopic (FTIR) analyses demonstrated that the seeds (cotyledons) of the non-irrigated and irrigated yellow lupine plants significantly differed with respect to their chemical composition. We believe that various protein types are present in the control and irrigated lupine seeds. However, at this stage of research, it is difficult to determine which of the observed changes are favorable or unfavorable for subsequent germination and seedling development, as well as for nutraceutical and taste properties of the seeds. This is an extremely interesting and important problem to be addressed in subsequent studies, all the more so, because the differences in the chemical composition of the seeds of irrigated and non-irrigated plants are species-specific [43].

Plant seeds are covered by seed coat and impregnated by cuticle and epicuticular waxes which protect them from environmental conditions, pathogens and insect attack $[38,68,69]$. This layer is also of great importance during the first stage of seed germination (imbibition). Our research revealed that irrigation of lupine plants during their cultivation affected the chemical composition of developing seeds coat. This modification influenced the subsequent germination of seeds. Similarly, as it was shown in the case of narrow-leaved lupine [43], the seeds produced by the irrigated yellow lupine plants also began to germinate faster. Due to the chemically changed coat of the seeds developed in the irrigated plants (revealed by spectroscopic analyses), the process of water absorption and seed imbibition may speed up, leading to quicker seed coat cracking and germination, similarly as it was observed in other seeds [69-71].

Imbibition of water causes the resumption of metabolic activity in the rehydrated seeds. During the next steps of germination catabolic enzymes (amylases, proteases) cause the breakdown of the stored substances (starch and proteins). After translocation of the hydrolyzed nutrients to the embryo proper and their subsequent assimilation, the cells of the embryo in the growing regions become metabolically very active, grow in size, begin proliferative activity and expansion to form the embryonic root and then young seedlings [72]. In order to mobilize storage substances and to make them available to the embryo axis, efficient functioning of a signaling network and activation of many genes associated with germination are necessary [73,74]. Different compounds are involved in the plant signaling network, among them sugars, hormones, nitric oxide, calcium ions $\left(\mathrm{Ca}^{2+}\right)$, hydrogen peroxide $\left(\mathrm{H}_{2} \mathrm{O}_{2}\right)$, and others [75-78].

Our studies demonstrated that in seeds produced by the irrigated yellow lupine plants, which began to germinate faster (like narrow-leaved lupine seeds, just after the first day), the growth of embryonic root was weaker. Probably, these seeds were not fully ready for the next phases (catabolic 
and/or anabolic) of germination yet, which requires adequate resources of enzymes, regulatory and signal molecules. This may also be concluded from different contents of chemical elements in the seeds, i.e., nitrogen (in the embryo axis of narrow-leaved lupine) and calcium (in the cotyledon near plumule of the yellow lupine). The appropriate level of nitrogen and suitable carbon/nitrogen balance is crucial for the gene expression during germination and young seedling growth [74], while calcium signaling is, for example, involved in the regulation of cell cycle progression and gene expression in response to abiotic stresses [75]. Since calcium content was limited in the cotyledon near plumule of the irrigated yellow lupine seeds, their embryonic roots may have grown more slowly. However, analysis of mitotic activity in the meristems of the yellow lupine embryonic roots did not show statistically significant differences between the seeds of irrigated and non-irrigated plants (which were pronounced in narrow-leafed lupine), while changes between them were observed mainly in the proportions at the first stage of mitosis. Also, no statistically significant changes in $\mathrm{H}_{2} \mathrm{O}_{2}$ content (clearly visible in narrow-leafed lupine) were observed. $\mathrm{H}_{2} \mathrm{O}_{2}$ as one of the constitutive attributes of plant root physiology together with peroxidases (Clas III, E.C.1.11.1.7.), which catalyze the reduction of $\mathrm{H}_{2} \mathrm{O}_{2}$ or its formation (in the peroxidative or hydroxylic cycle, respectively). These processes are connected with cell wall loosening and root elongation during seed germination [79-82]. Such a result may suggest that irrigation during the growth and development of both species of plants (in an attempt to reduce drought stress) caused modifications in slightly different branches of signaling or metabolic networks and were reflected in different responses at the cell and tissue level.

\section{Materials and Methods}

\subsection{Plant Cultivation}

The research consisted in a field experiment carried out for three consecutive years at the Złotniki Research Station $\left(52^{\circ} 29^{\prime} N, 16^{\circ} 49^{\prime}\right.$ E,Poznań University of Life Sciences, Poland). The study was conducted as a stationary experiment (in a randomized complete block design with 4 replications) on grey-brown podzolic soil ( $\mathrm{pH}=4.8$ measured in $1 \mathrm{M} \mathrm{KCL} ; 1.3 \%$ organic matter: $50-110 \mathrm{mg} \mathrm{kg}^{-1} \mathrm{P}$, 115-195 $\mathrm{mg} \mathrm{kg}^{-1} \mathrm{~K}$ ) in 4-crop rotation. The yellow lupine (L. luteus L., cultivar Mister, certified seeds from PHR breeder, Poznań, Poland) was sown $\left(150 \mathrm{~kg} \mathrm{ha}^{-1}\right)$ in early April. Sowing depth was $4 \mathrm{~cm}$ and the row distance was $18 \mathrm{~cm}$. The main plot treatments were natural rainfall (non-irrigated), and natural rainfall plus irrigations (irrigated). There was a gap of $6 \mathrm{~m}$ in width between non-irrigated and irrigated parts of plots. Irrigations were applied during flowering, pod and seed ripening (May, June, July) when consumption of $30 \%$ of the readily available soil moisture (measured by the gravimetric method) was observed in the $0.30 \mathrm{~m}$ root zone. The irrigation water (of good quality, containing $114 \mathrm{Ca}^{2+}, 7.4 \mathrm{Mg}^{2+}$, $0 \mathrm{Na}^{+}, 0 \mathrm{~K}^{+},<1 \mathrm{Fe}^{3+}, 356 \mathrm{CaCO}_{3} \mathrm{mg} \cdot \mathrm{L}^{-1} ; \mathrm{pH} 7.3$ ) was taken from a small reservoir near the experimental site. Irrigation was performed using a water pump with aluminium outlet pipes (110 $\mathrm{mm}$ in diameter) and a rotary sprinkler. The diameters of the nozzles were $7 \mathrm{~mm}$ (NAAN 233/91) and the discharge rate was $5 \mathrm{~L} \cdot \mathrm{h}^{-1}$ (with the operating pressure of $0.35-0.4 \mathrm{MPa}$ ). The main pipes with the rotary sprinkler were placed in the middle of irrigated parts of plots. The mean dose of water and time of irrigation during vegetation period were $30-35 \mathrm{~mm}$ and $6-7 \mathrm{~h}$, respectively, while the mean daily air temperatures and total precipitation in the vegetation periods in May, June and July were $15.3,18.4,17.5^{\circ} \mathrm{C}$ and $17.5,62.4$, $214.8 \mathrm{~mm}$, respectively (data from the Agrometeorological Observatory in Złotniki).

\subsection{Yield Assessment}

Ten plants of yellow lupine were collected randomly two days before harvest and were used to measure seed yield (expressed as g per plant).

\subsection{Seed Germination for Cytological Study}

Seeds of lupine were sown on wet filter paper in Petri dishes $(10$ seeds $/ \emptyset 15 \mathrm{~cm})$ and germinated at room temperature for maximum 4 days in the dark. 


\subsection{Cytophotometry}

Apical fragments of embryo roots and cotyledons were fixed in cold Carnoy's mixture (glacial acetic acid and absolute ethanol; $1: 3 ; v / v)$ for $1 \mathrm{~h}$. Following rehydration (70\% ethanol, 30\% ethanol, distilled water), the roots were hydrolyzed in $4 \mathrm{M} \mathrm{HCl}$ for $1 \mathrm{~h}$ and stained with Schiff's reagent (pararosaniline; Sigma-Aldrich, St. Louis, MO, USA) according to the standard methods [83]. After rinsing in $\mathrm{SO}_{2}$-water and then in distilled water, fragments of cotyledons from the selected zones and 1.5-mm-long apical segments of the roots were cut off and squashed onto Super-Frost (Menzel-Gläser, Braunschweig, Germany) microscope slides. Following freezing with dry ice, cover slips were removed, and the dehydrated dry slides were embedded in Canada balsam. Nuclear DNA content was evaluated by means of microdensitometry using a Jenamed 2 microscope (Carl Zeiss, Jena, Germany) with the computer-aided Cytophotometer v1.2 (Forel, Lodz, Poland). The Feulgen-stained cell nuclei were measured at $565 \mathrm{~nm}$. Microscopic slides were used also to analyze the mitotic and phase indexes.

\subsection{Electrophoretic Separation of Proteins}

P-PER Plant Protein Extraction Kit (Pierce) supplemented with Protease Inhibitor Cocktail (Sigma) was used for total protein extraction. The Lowry procedure was used to determine the total level of proteins in the solution [84]. Whole-cell protein extracts were fractionated on NuPAGE ${ }^{\circledR}{ }^{\circledR}$ Novex ${ }^{\circledR \circledR} 4-12 \%$ Bis-Tris gel, in NuPAGE ${ }^{\circledR}$-MES SDS (50 mM MES, 50 mMTris, 0.1\% SDS, $1 \mathrm{mM}$ EDTA) buffer ( $\mathrm{pH} 7.3 ; 200 \mathrm{~V} ; 110-125 \mathrm{~mA}$ ). Analysis of staining intensity (Coomassie ${ }^{\mathrm{TM}}$ ) of the bands obtained by the electrophoretic separation of proteins was carried out using the Gel Analyzer 2010a (http://www.gelanalyzer.com).

\subsection{FTIR Analysis of Lupine Seeds}

The Fourier transform infrared spectroscopy technique (FT-IR;, an analytical technique offering a possibility of chemical identification of samples) is based on the fact that chemical substances show selective absorption in infrared regions. The molecules vibrate, after absorption of IR radiations, giving rise to the spectrum of absorption [85]. The FTIR spectra were recorded in the range between 4000 and $500 \mathrm{~cm}^{-1}$ with a Nicolet ${ }^{\mathrm{TM}} 6700$ spectrometer (Thermo Scientific, Waltham, MA, USA); a spectral resolution was $4 \mathrm{~cm}^{-1}$. The spectra were obtained using ATR and DRIFTS techniques. Room temperature reflectance spectra were recorded using a Spectra-Tech DRIFTS and ATR accessory (Spectra-Tech Inc., Hanover Park, IL, USA). Eachsample was analyzed directly on the sample cup after roughing it with silicon carbide $(\mathrm{SiC})$ paper. A small disc of $\mathrm{SiC}$ paper was used to rub off a small amount of sample. Pieces of clean $\mathrm{SiC}$ paper was used as the background. For the FT-IR/horizontal attenuated total reflectance (HATR) technique, a diamond crystal was used. HATR technique provides a simple means of direct handling of plant material. The lupine samples were placed in a HATR crystal and a beam of infrared radiation is directed onto a diamond crystal. The wave of radiation extends beyond the surface of the crystal and comes into the sample. The resultant radiation was measured and plotted as a function of the wave number.

\subsection{SEM/EDS Microanalysis}

Scanning electron microscope (SEM) which produces images of samples by scanning them with a focused beam of electrons (various characteristics of the sample e.g., size and shape) was used for morphological analysis of seed samples. The EDS technique (Energy Dispersive Spectroscopy), was used to identify different chemical elements present in lupine seeds as described by He and coworkers [86] and Psaras and Manetas [87], with modifications. Mature, dry seeds of yellow lupine from control and irrigated plants (five seeds of each kind) were cut on half and without sputter coating with gold were observed with a SEM, model FEI INSPECT S50 (FEI, Hillsboro, OR, USA). X-ray microanalyses were made with the EDS system (Ametek, Weiterstadt, Germany) connected to the SEM, in six selected points of each seed (embryo axis, cotyledon near plumule, cotyledon center, cotyledon 
near radicle, seed coat and plumule, Figure $7 \mathrm{a}, \mathrm{b}$ ). In all cases the voltage was $20 \mathrm{kV}$ (for micrograhs 10 $\mathrm{kV}$ ), the pressure $60 \mathrm{~Pa}$, spod size 3 and live time 30s. EDS spectra were analyzed and elements whose presence was recorded in the form of peaks summarized in tables (eZAF Smart Quant Results). The content of chemical elements (weight \%) were estimated statistically.

\subsection{Histochemical Localization of $\mathrm{H}_{2} \mathrm{O}_{2}$}

The generation of $\mathrm{H}_{2} \mathrm{O}_{2}$ was observed using peroxidase-catalyzed 3,3-diaminobenzidine (DAB; Sigma) polymerization test, according to Thordal-Christensen and cowerkers [88] with some modifications [89]. Seedlings of lupine were incubated for $12 \mathrm{~h}$ in a solution containing $1 \mathrm{mg} \cdot \mathrm{mL}^{-1}$ DAB dissolved in Tris buffer (100 mM Tris, $10 \mathrm{mM}$ EDTA-2Na, $100 \mathrm{mM} \mathrm{NaCl}, \mathrm{pH} 7.6)$. Additional "negative control" series comprised of lupine seedlings incubated with $1 \mathrm{mM}$ ascorbic acid (AA; Sigma). Then the roots were fixed in PBS-buffered 3.7\% paraformaldehyde solution for $40 \mathrm{~min}\left(4^{\circ} \mathrm{C}\right)$, washed with PBS (three times) and incubated in a citric acid buffered digestion solution ( $\mathrm{pH}$ 5.0) containing $2.5 \%$ pectinase, $2.5 \%$ cellulose and $2.5 \%$ pectolyase, at $37^{\circ} \mathrm{C}$ for $30 \mathrm{~min}$. Afterwards the roots were washed with PBS and squashed onto microscope glass slides in a mixture of glycerol and PBS $(9: 1 ; \mathrm{v} / \mathrm{v})$. $\mathrm{H}_{2} \mathrm{O}_{2}$ was visualized under the SMZ-2T microscope (equipped with DXM 1200 CCD camera Nikon, Tokyo, Japan) as a reddish-brown coloration.

\subsection{Statistical Analysis}

The differences between values obtained in the particular experiments were assessed with the analysis of variance (ANOVA) and following post-hoc Tukey's test, the Student's $t$-test or the Mann-Whitney $U$ test. The choice of the test to the individual experiment was indicated in the description of the graphs.

\section{Conclusions}

In conclusion, our research clearly indicates that irrigation of crops in drought conditions may prevent them from drying out, but due to the lack of appropriate parameters of this agrotechnical practice, it does not always lead to higher yields. Irrigation can affect seed formation, changes the level of ploidy of cotyledon cells. Furthermore, it may interfere with the quality of storage substances and influence seed germination. In connection with the above, we believe that the studies on the modifications of stressful environmental conditions on the arable crops are necessary and justified and that the agrotechnical procedure of plant irrigation (a subject of our current work) must be carefully selected and developed for the individual plant species.

Author Contributions: G.S. conceived and designed a field research. I.C. and J.T.P. conceived and designed a laboratory research. A.F. and Ł.S. conducted a field experiment and provided seeds. J.L., A.T.D., A.B., A.Ż., M.A., K.W. and J.P. conducted laboratory experiments. K.W. conducted statistical analysis. I.C. and J.P. analyzed the data. J.P. wrote the manuscript. J.M. conducted a language correction. All authors read and approved the manuscript.

Funding: Equipment for this research was partially financed by EU funds via the projects with contract numbers: POPW.01.03.00-20-034/09-00 and POPW.01.03.00-20-004/11-00. The paper has received financial support from: 1) Ministry of Science and Higher Education, programme "Regional Initiative of Excellence" in years 2019-2022, Project No. 005/RID/2018/19;2) University of Łódź, statutory subsidy No. 506/1141, Project No. B1811000000053.01; 3) Polish Ministry of Science and Higher Education under subsidy for maintaining the research potential of the Faculty of Biology, University of Bialystok.

Acknowledgments: We thank M. Fronczak for help in preparing this manuscript in English.

Conflicts of Interest: The authors declare no conflict of interest.

\section{Abbreviations}

FTIR Fourier transform infrared spectroscopy

SEM Scanning electron microscope

EDS Energy dispersive spectroscopy 


\section{References}

1. Sujak, A.; Kotlarz, A.; Strobel, W. Compositional and nutritional evaluation of several lupin seeds. Food Chem. 2006, 98, 711-719. [CrossRef]

2. Fernández-Pascual, M.; PueyoMaría, J.J.; Lucas, M.M. Singular features of the Bradyrhizobium-Lupinus symbiosis. Dyn. Soil Dyn. Plant 2007, 1, 1-16.

3. Coba de la Peña, Y.; Pueyo, J.J. Legumes in the reclamation of marginal soils, from cultivar and inoculants selection to transgenic approaches. Agron. Sustain. Dev. 2012, 32, 65-91. [CrossRef]

4. Lucas, M.M.; Stoddard, F.L.; Annicchiarico, P.; Frías, J.; Martínez-Villaluenga, C.; Sussmann, D.; Duranti, M.; Seger, A.; Zander, P.M.; Pueyo, J.J. The future of lupin as a protein crop in Europe. Front. Plant Sci. 2015, 6, 705. [CrossRef] [PubMed]

5. Wilmowicz, E.; Kućko, A.; Burchardt, S.; Przywieczerski, T. Molecular and hormonal aspects of drought-triggered flower shedding in yellow lupine. Int. J Mol. Sci. 2019, 20, 3731. [CrossRef]

6. Graham, P.H.; Vance, C.P. Legumes: Importance and constraints to greater use. Plant Physiol. 2003, 131, 872-877. [CrossRef]

7. Straková, E.; Suchý, P.; Večerek, V.; Šerman, V.; Mas, N.; Jůzl, M. Nutritional composition of seeds of genus Lupinus. Acta Vet. Brno 2006, 75, 489-493. [CrossRef]

8. Ogura, T.; Ogihara, J.; Sunairi, M.; Takeishi, H.; Aizawa, T.; Olivos-Trujillo, M.R.; Maureira-Butler, I.J.; Salvo-Garrido, H.E. Proteomic characterization of seeds from yellow lupin (Lupinus luteus L.). Proteomics 2014, 14, 1543-1546. [CrossRef]

9. Juzoń, K.; Czyczyło-Mysza, I.; Marcińska, I.; Dziurka, M.; Waligórski, P.; Skrzypek, E. Polyamines in yellow lupin (Lupinus luteus L.) tolerance to soil drought. Acta Physiol. Plant. 2017, 39, 202. [CrossRef]

10. Bettzieche, A.; Brandsch, C.; Eder, K.; Stangl, G.I. Lupin protein acts hypocholesterolemic and increases milk fat content in lactating rats by influencing the expression of genes involved in cholesterol homeostasis and triglyceride synthesis. Mol. Nutr. Food Res. 2009, 53, 1134-1142. [CrossRef]

11. Duranti, M.; Morazzoni, P. Nutraceutical properties of lupin seed proteins. A great potential still waiting for full exploitation. Agro Food Ind. Hi Technol. 2011, 22, 20-23.

12. Walsh, C.J.; Guinane, C.M.; O'Toole, P.W.; Cotter, P.D. Beneficial modulation of the gut microbiota. FEBS Lett. 2014, 588, 4120-4130. [CrossRef] [PubMed]

13. Strozycki, P.M.; Szczurek, A.; Lotocka, B.; Figlerowicz, M.; Legocki, A.B. Ferritins and nodulation in Lupinus luteus: Iron management in indeterminate type nodules. J. Exp. Bot. 2007, 58, 3145-3153. [CrossRef] [PubMed]

14. Bieniaszewski, T.; Szwejkowski, Z.; Fordoński, G. Impact of temperature and rainfall distribution over 1989-1996 on the biometric and structural characteristics as well as on the 'Juno' yellow lupin yielding. EJPAU 2000, 3. Available online: http://www.ejpau.media.pl/volume3/issue2/agronomy/art-02.html (accessed on 5 November 2019).

15. Faligowska, A.; Szukała, J. Influence of irrigation and soil tillage systems on vigour and sowing value of yellow lupine seeds. Sci. Nat. Technol. 2012, 2, 26.

16. Podleśny, J.; Podleśna, A. Wpływ wysokiej temperatury w okresie kwitnienia na wzrost, rozwój i plonowanie łubinu żółtego. Acta Agrophyscia 2012, 19, 825-834.

17. Pszczółkowska, A.; Olszewski, J.; Płodzień, K.; Kulik, T.; Fordoński, G.; Żuk-Gołaszwska, K. Effect of the water stress on the productivity of selected genotypes of pea (Pisum sativum L.) and yellow lupin (Lupinus luteus L.). Electron. J. Polish Agric. Univ, Agron. 2003, 6, 1.

18. Gresta, F.; Wink, M.; Prins, U.; Abberton, M.; Capraro, J.; Scarafoni, A.; Hill, G. Lupins in european cropping system. In Legumes in Cropping System; Murphy-Bokern, D., Stoddard, F.L., Watson, C.A., Eds.; CABI Publishing: Wallingford, UK, 2017; pp. 88-108.

19. Okamoto, K.; Sagata, N. Mechanism for inactivation of the mitotic inhibitory kinase Wee1 at M phase. Proc. Nat. Acad. Sci. USA 2007, 104, 3753-3758. [CrossRef]

20. Farooq, M.; Wahid, A.; Kobayashi, N.; Basra, A.S.M. Plant drought stress: Effects, mechanisms and management. Agron. Sustain. Dev. 2009, 29, 185-212. [CrossRef]

21. Lisar, S.Y.S.; Motafakkerazad, R.; Hossain, M.M.; Rahman, I.M.M. Water Stress in Plants: Causes, Effects and Responses. In Water Stress; Rahman, I.M.M., Ed.; InTech: London, UK, 2012; pp. 1-16. 
22. Osakabe, Y.; Osakabe, K.; Shinozaki, K.; Tran, L.S.P. Response of plants to water stress. Front. Plant. Sci. 2014, 5, 1-8. [CrossRef]

23. Shanker, A.K.; Maheswari, M.; Yadav, S.K.; Desai, S.; Bhanu, D.; Attal, N.B.; Venkateswarlu, B. Drought stress responses in crops. Funct. Integr. Genomics 2014, 14, 11-22. [CrossRef] [PubMed]

24. Yadav, S.; Sharma, K.D. Molecular and Morphophysiological Analysis of Drought Stress in Plants Summy. In Plant Growth; Rigobello, E., Ed.; InTech: London, UK, 2016; pp. 149-173.

25. Kang, Y.; Khan, S.; Ma, X. Climate change impacts on crop yield, crop water productivity and food security A review. Prog. Nat. Sci. 2009, 19, 1665-1674. [CrossRef]

26. Morison, J.I.; Baker, N.; Mullineaux, P.; Davies, W. Improving water use in crop production. Philos. Trans. R. Soc. Lond. B Biol. Sci. 2008, 363, 639-658. [CrossRef] [PubMed]

27. Almer, C.; Laurent-Lucchetti, J.; Oechslin, M. Water scarcity and rioting: Disaggregated evidence from Sub-Saharan Africa. J. Environ. Econ. Manage. 2016, 86, 193-209. [CrossRef]

28. Cox, F.R.; Sullivan, G.A.; Martin, C.K. Effect of calcium and irrigation treatments on peanut yield, grade and seed quality 1. Peanut Sci. 1976, 3, 81-85. [CrossRef]

29. Holden, N.M.; Brereton, A.J. Adaptation of water and nitrogen management of spring barley and potato as a response to possible climate change in Ireland. Agric. Water Manag. 2006, 82, 297-317. [CrossRef]

30. Zhao, H.L.; Cui, J.Y.; Zhou, R.L.; Zhang, T.H.; Zhao, X.Y.; Drake, S. Soil properties, crop productivity and irrigation effects on five croplands of Inner Mongolia. Soil Tillage Res. 2007, 93, 346-355. [CrossRef]

31. Kassab, O.M.; Abo Ellil, A.A.; Abdallah, E.F.; Ibrahim, M.M. Performance of some chickpea cultivars under sprinkler irrigation treatments in sandy soil. Aust. J. Basic App. Sci. 2012, 6, 618-625.

32. Levidow, L.; Zaccaria, D.; Maia, R.; Vivas, E.; Todorovic, M.; Scardigno, A. Improving water-efficient irrigation: Prospects and difficulties of innovative practices. Agric. Water Manag. 2014, 146, 84-94. [CrossRef]

33. Breen, A.N.; Richards, J.H. Irrigation and fertilization effects on seed number, size, germination and seedling growth: Implications for desert shrub establishment. Oecologia 2008, 157, 13-19. [CrossRef]

34. Faligowska, A.; Panasiewicz, K.; Szymańska, G.; Bartos-Spychała, M. The seeds quality of yellow lupine depending on selected agrotechnical factors. Prog. Plant Prot. 2013, 53, $293-296$.

35. Faligowska, A.; Panasiewicz, K.; Szukała, J.; Koziara, W. Germination and vigour of narrow-leaved lupin seeds as the effect of irrigation of parent plants and cultivation in different soil tillage systems. Polish J. Agron. 2016, 24, 3-8.

36. Tooke, P.B. Fourier self-deconvolution in IR spectroscopy. Trends Analyt. Chem. 1988, 7, 130-136. [CrossRef]

37. Lamba, O.P.; Borchman, D.; Sinha, S.K.; Shah, J.; Renugopalakrishnan, V.; Yappert, M.C. Estimation of the secondary structure and conformation of bovine lens crystallins by infrared spectroscopy: Quantitative analysis and resolution by Fourier self-deconvolution and curve fit. Biochim. Biophys. Acta 1993, 1163, 113-123. [CrossRef]

38. Ribeiro da Luz, B. Attenuated total reflectance spectroscopy of plant leaves: A tool for ecological and botanical studies. New Phytol. 2006, 172, 305-318. [CrossRef]

39. Żarski, J.; Dudek, S.; Kuśmierek-Tomaszewska, R.; Rolbiecki, R.; Rolbiecki, S. Prognozowanie efektów nawadniania roślin na podstawie wybranych wskaźników suszy meteorologicznej i rolniczej. Rocznik Ochr. Środ. 2013, 15, 2185-2203.

40. Davies, C.L.; Turner, D.W.; Dracup, M. Yellow lupin (Lupinus luteus) tolerates waterlogging better than narrow-leaved lupin (L. angustifolius). I. Schoot and root growth in a controlled environment. Aust. J. Agric. Res. 2000, 51, 701-709. [CrossRef]

41. Dracup, M.; Turner, N.C.; Tang, C.; Reader, M.; Palta, J. Responses to abiotic stresses. Chapter 8. In Lupins as Crop Plants: Biology, Production and Utilization; Gladstones, J.S., Atkins, C.A., Hamblin, J., Eds.; CABI: Wallingford, UK, 1998; pp. 227-262.

42. Płażek, A.; Dubert, F.; Kopeć, P.; Dziurka, M.; Kalandyk, A.; Pastuszak, J.; Wolko, B. Seed hydropriming and smoke water significantly improve low-temperature germination of Lupinus angustifolius L. Int. J. Mol. Sci. 2018, 19, 992. [CrossRef]

43. Winnicki, K.; Ciereszko, I.; Leśniewska, J.; Dubis, A.T.; Basa, A.; Żabka, A.; Hołota, M.; Sobiech, Ł.; Faligowska, A.; Skrzypczak, G.; et al. Irrigation affects characteristics of Barrow-leaved lupin (Lupinus angustifolius L.). Planta 2019, 249, 1731-1746. [CrossRef]

44. Ambika, S.; Manonmani, V.; Somasundaram, G. Review on effect of seed size on seedling vigour and seed yield. Res. J. Seed Sci. 2014, 7, 31-38. [CrossRef] 
45. Peksen, E.; Peksen, A.; Bozoglu, H.; Gulumser, A. Some seed traits and their relationships to seed germination and field emergence in pea (Pisum sativum L.). J. Agron. 2004, 3, 243-246.

46. Rastegar, Z.; Kandi, M.A.S. The effect of salinity and seed size on seed reserve utilization and seedling growth of soybean (Glycin max). Int. J. Agron. Plant Prod. 2011, 2, 1-4.

47. Farhoudi, R.; Motamedi, M. Effect of salt stress and seed size on germination and early seedling growth of safflower (Carthamus tinctorius L.). Seed Sci. Technol. 2010, 38, 73-78. [CrossRef]

48. Bourdon, M.; Pirrello, J.; Cheniclet, C.; Coriton, O.; Bourge, M.; Brown, S.; Moïse, A.; Peypelut, M.; Rouyère, V.; Renaudin, J.P.; et al. Evidence for karyoplasmic homeostasis during endoreduplication and a ploidy-dependent increase in gene transcription during tomato fruit growth. Development 2012, 139, 3817-3826. [CrossRef]

49. Takahashi, N.; Umeda, M. Cytokinins promote onset of endoreplication by controlling cell cycle machinery. Plant Signal Behav. 2014, 9, e29396. [CrossRef]

50. Scholes, D.R.; Paige, K.N. Plasticity in ploidy: A generalized response to stress. Trends Plant Sci. 2015, 20, 165-175. [CrossRef]

51. Lee, H.O.; Davidson, J.M.; Duronio, R.J. Endoreplication: Polyploidy with purpose. Genes Develop. 2009, 23, 2461-2477. [CrossRef]

52. Knake-Sobkowicz, S.; Marciniak, K. Cellular accumulation of protein bodies and changes in DNA ploidy level during seed development of Lathyrus tuberosus L. Acta Biol. Crac. Series Bot. 2005, 47, 147-157.

53. Dante, R.A.; Larkins, B.A.; Sabelli, P.A. Cell cycle control and seed development. Front. Plant. Sci. 2014, 5, 1-14. [CrossRef]

54. Leiva-Neto, J.T.; Grafi, G.; Sabelli, P.A.; Dante, R.A.; Woo, Y.; Maddock, S.; Gordon-Kamm, W.J.; Larkins, B.A. A dominant negative mutant of cyclin-dependent kinase A reduces endoreduplication but not cell size or gene expression in maize endosperm. Plant Cell 2004, 16, 1854-1869. [CrossRef]

55. Joubès, J.; Chevalier, C. Endoredupication in higher plants. Plant Mol. Biol. 2000, 43, 735-745. [CrossRef] [PubMed]

56. González-Sama, A.; Coba de la Peña, T.; Kevei, Z.; Mergaert, P.; Lucas, M.M.; de Felipe, M.R.; Kondorosi, E.; Pueyo, J.J. Nuclear DNA endoreduplication and expression of the mitotic inhibitor Ccs52 associated to determinate and lupinoid nodule organogenesis. Mol. Plant-Microbe Inter. J. 2006, 19, 176-180. [CrossRef] [PubMed]

57. Park, S.; Yeung, E.C.; Paek, K. Endoredupication in Phalaenopsis is affected by light quality from light-emitting diodes during somatic embryogenesis. Plant Biotechnol. Rep. 2010, 4, 303-309. [CrossRef]

58. Chevalier, C.; Nafati, M.; Mathieu-Rivet, E.; Bourdon, M.; Frangne, N.; Cheniclet, C.; Renauldin, J.-P.; Gévaudant, F.; Hernould, M. Elucidating the functional role of endoreduplication in tomato fruit development. Ann. Bot. 2011, 107, 1159-1169. [CrossRef]

59. Kondorosi, E.; Roudier, F.; Gendreau, E. Plant cell size control: Growing by ploidy? Curr. Opin. Plant Biol. 2000, 3, 488-492. [CrossRef]

60. Breuer, C.; Braidwood, L.; Sugimoto, K. Endocycling in the path of plant development. Curr. Opin. Plant Biol. 2014, 17, 78-85. [CrossRef]

61. Lqari, H.; Pedroche, J.; Girón-Calle, J.; Vioque, J.; Millán, F. Purification and partial characterization of storage proteins in Lupinus angustifolius seeds. Grasas y Aceites 2004, 55, 364-369.

62. Duranti, M.; Consonni, A.; Magni, C.; Sessa, F.; Scarafoni, A. The major proteins of lupin seed: Characterisation and molecular properties for use as functional and nutraceutical ingredients. Trends Food Sci. Technol. 2008, 19, 624-633. [CrossRef]

63. Foley, R.C.; Jimenez-Lopez, C.; Kamphuis, L.G.; Hane, J.K.; Melser, S.; Singh, K.B. Analysis of conglutin seed storage proteins across lupin species using transcriptomic, protein and comparative genomic approaches. BMC Plant Biol. 2015, 15, 106. [CrossRef]

64. Jimenez-Lopez, J.C.; Melser, S.; DeBoer, K.; Thatcher, L.F.; Kamphuis, L.G.; Foley, R.C.; Singh, K.B. Narrow-leaved lupin (Lupinus angustifolius) $\beta 1$ - and $\beta 6$-conglutin proteins exhibit antifungal activity, protecting plants against necrotrophic pathogen induced damage from Sclerotinia sclerotiorum and Phytophthora nicotianae. Front. Plant. Sci. 2016, 7, 1856. [CrossRef]

65. Barciszewska-Pacak, M.; Milanowska, K.; Knop, K.; Bielewicz, D.; Nuc, P.; Plewka, P.; Pacak, A.M.; Vazquez, F.; Karłowski, W.; Jarmołowski, A.; et al. Arabidopsis microRNA expression regulation in a wide range of abiotic stress responses. Front Plant Sci. 2015, 6, 410. [CrossRef] [PubMed] 
66. Battaglia, M.; Covarrubis, A.A. Late Embryogenesis Abundant (LEA) proteins in legumes. Front. Plant Sci. 2013, 4, 190. [CrossRef] [PubMed]

67. Shrivastava, P.; Kumar, R. Soil salinity: A serious environmental issue and plant growth promoting bacteria as one of the tools for its alleviation. Saudi. J. Biol. Sci. 2015, 22, 123-131. [CrossRef] [PubMed]

68. Heredia, A. Biophysical and biochemical characteristics of cutin, a plant barrier biopolymer. Bioch. Bioph. Acta 2003, 1620, 1-7. [CrossRef]

69. Shao, S.; Meyer, C.J.; Ma, F.; Peterson, C.A.; Bernards, M.A. The outermost cuticle of soybean seeds: Chemical composition and function during imbibition. J. Exp. Bot. 2007, 58, 1071-1082. [CrossRef]

70. Clua, A.A.; Gimenez, D.O. Environmental factors during seed development of narrow-leaved bird's-foot-trefoil (Lotus tenuis) influences subsequent dormancy and germination. Grass Forage Sci. 2003, 58, 333-338. [CrossRef]

71. Clua, A.; Fernandez, G.; Ferro, L.; Dietrich, M. Drought stress conditions during seed development of narrowleaf birdsfoot trefoil (Lotus glaber) influences seed production and subsequent dormancy and germination. Lotus Newsl. 2006, 36, 58-63.

72. Ranal, M.A.; Santana, D.G. How and why to measure the germination process? Rev. Bras. Bot. 2006, $29,1-11$. [CrossRef]

73. Gallardo, K.; Job, C.; Groot, S.P.C.; Puype, M.; Demol, H.; Vandekerckhove, J.; Job, D. Proteomic analysis of Arabidopsis seed germination and priming. Plant Physiol. 2001, 126, 835-848. [CrossRef]

74. Osuna, D.; Prieto, P.; Aguilar, M. Control of seed germination and plant development by carbon and nitrogen availability. Front. Plant Sci. 2015, 6, 1023. [CrossRef]

75. Tuteja, N.; Mahajan, S. Calcium signaling network in plants. Plant Signal Behav. 2007, 2, 79-85. [CrossRef] [PubMed]

76. Polit, J.T.; Ciereszko, I. In situ activities of hexokinase and fructokinase in relation tophosphorylation status of root meristem cells of Vicia faba during reactivation from sugar starvation. Physiol. Plant. 2009, 135, 342-350. [CrossRef] [PubMed]

77. Polit, J.T.; Ciereszko, I. Sucrose synthase activity and carbohydrates content in relation to phosphorylation status of Vicia faba root meristems during reactivation from sugar depletion. J. Plant Physiol. 2012, 169, 1597-1606. [CrossRef] [PubMed]

78. Kurusu, T.; Kimura, S.; Tada, Y.; Kaya, H.; Kuchitsu, K. Plant signaling networks involving reactive oxygen species and $\mathrm{Ca}^{2+}$. In Handbook on reactive oxygen species (ROS): Formation mechanisms, physiological roles and common harmful effects; Suzuki, M., Yamamoto, S., Eds.; Nova Science Publishers: Hauppauge, NY, USA, 2013; pp. 315-324.

79. Passardi, F.; Penel, C.; Dunand, C. Performing the paradoxical: How plant peroxidases modify the cell wall. Trends Plant Sci. 2004, 9, 534-540. [CrossRef] [PubMed]

80. Dunand, C.; Crèvecoeur, M.; Penel, C. Distribution of superoxide and hydrogen peroxide in Arabidopsis root and their influence on root development: Possible interaction with peroxidases. New Physiol. 2007, 174, 332-341. [CrossRef] [PubMed]

81. Liu, X.; Xing, D.; Li, L.; Zhang, L. Rapid determination of seed vigor based on the level of superoxide generation during early imbibitions. Photochem. Photobiol. Sci. 2007, 6, 767-774. [CrossRef]

82. Szopińska, D. Effects of hydrogen peroxide treatment on the germination, vigour and health of Zinnia elegans seeds. Folia Hort. 2014, 26, 19-29. [CrossRef]

83. Maszewski, J.; Kaźmierczak, A.; Polit, J. Cell cycle agrest in antheridial extract-treated Root meristems of Allium cepa and Melandrium noctiflorum. Folia Histochem. Cytobiol. 1998, 36, 35-43.

84. Lowry, O.H.; Rosenbrough, N.J.; Farr, A.L.; Randall, R.J. Protein measurement with the Folin Phenol Reagen. J. Biol. Chem. 1951, 193, 265-275.

85. Dubis, E.N.; Dubis, A.T.; Popławski, J. Determination of the aromatic compounds in plant cuticular waxes using FT-IR spectroscopy. J. Mol. Struct. 2001, 596, 83-88. [CrossRef]

86. He, H.; Veneklaas, E.J.; Kuo, J.; Lambers, H. Physiological and ecological significance of biomineralization in plants. Trends Plant Sci. 2014, 19, 166-174. [CrossRef] [PubMed]

87. Psaras, G.K.; Manetas, Y. Nickel localization in seeds of the metal hyperaccumulator Thlaspi pindicum Hausskn. Ann. Bot. 2001, 88, 513-516. [CrossRef] 
88. Thordal-Christensen, H.; Zhang, Z.; Wei, Y.; Collinge, D.B. Subcellular localization of H2O2 in plants: H2O2 accumulation in papillae and hypersensitive response during the barley-powdery mildew interaction. Plant J. 1997, 11, 1187-1194. [CrossRef]

89. Żabka, A.; Polit, J.T.; Maszewski, J. DNA replication stress induces deregulation of the cell cycle events in root meristems of Allium cepa. Ann. Bot. 2012, 110, 1581-1591. [CrossRef] 